\title{
The key role of sphingosine kinases in the molecular mechanism of neuronal cell survival and death in an experimental model of Parkinson's disease
}

\author{
Joanna A. Pyszko, Joanna B. Strosznajder \\ Department of Cellular Signalling, Mossakowski Medical Research Centre, Polish Academy of Sciences, Warsaw, Poland
}

\begin{abstract}
Sphingosine kinases (Sphk1/2 EC 2.7.1.91) are responsible for synthesis of sphingosine-1-phosphate (S1P) and for regulation of the bioactive sphingolipids homeostasis. Sphingosine-1-phosphate can act as a potent messenger in an autocrine/paracrine manner through five specific $G$ protein-coupled receptors (GPCR) S1P1-5. This sphingolipid is involved in the mechanism of transcription, mitochondrial function, neuronal viability and degeneration. Until now the involvement of Sphk $1 / 2$ and sphingolipid alterations in Parkinson's disease (PD) remains unknown. Recent studies have indicated the role of sphingolipids in the regulation of alpha-synuclein (ASN) in the PD brain. Our latest data demonstrated significant inhibition of Sphk1 gene expression and activity in an in vitro PD model, induced by 1-methyl-4-phenylpyridinium (MPP+). The aim of this study was to investigate the role of Sphks inhibition in ASN secretion and in the molecular mechanism of neuronal death in the PD model. Our study was carried out using neuronal dopaminergic SH-SYSY control cells, transfected with the human gene for ASN or with an empty vector. These cells were treated with MPP+ (1-3 mM), which represents an experimental PD model, or with the Sphks inhibitor (1-5 $\mu M$ SKI II) for 3-24 h. Our data indicated that MPP+ (3 mM) induced significant alterations of Sphks and SIP lyase (SPL) gene expression. Reduced activity of Sphk1 and Sphk2 in the cytosolic fraction and in the crude nuclear fraction, respectively, was observed. Sphks inhibition evoked enhancement of ASN secretion, suppression of PI3K/AKt phosphorylation and activation of gene expression for the pro-apoptotic $\mathrm{BCl}-2$ proteins Bax and BH3-only protein Harakiri. Moreover, a lower level of cytochrome $c$ in the mitochondrial fraction and caspase-dependent degradation of DNA-bound enzyme poly(ADP-ribose) polymerase (PARP-1) were observed. The caspase inhibitor (20 $\mu M$ Z-VAD$F M K)$ significantly enhanced neuronal cell viability in MPP+ oxidative stress. However, exogenous $S 1 P(1 \mu M)$ exerted a more efficient neuroprotective effect as compared to Z-VAD-FMK. In summary, these data indicated that Sphk1 inhibition plays an important role in caspase-dependent apoptotic neuronal death in an experimental PD model.
\end{abstract}

Key words: sphingosine kinases, dopaminergic neurons, apoptosis, PD model.

Communicating author:

Prof. M.D., Ph.D. Joanna B. Strosznajder, Department of Cellular Signalling Mossakowski Medical Research Centre Polish Academy of Sciences, e-mail: jstrosznajder@imdik.pan.pl 


\section{Introduction}

Sphingosine kinases (Sphk1 and Sphk2) catalyse ATP-dependent phosphorylation of sphingosine (Sph) to sphingosine 1-phosphate (S1P). Sphks are crucial enzymes in maintaining a balance between the lipid signalling molecules, such as ceramide/sphingosine, and S1P $[36,37,50,53]$. Sphk1 and Sphk2 share overall homology and synthesize S1P, which depending on intracellular localisations of Sphks isoforms plays different roles within the cell $[36,50,55]$. Sphk2 is located mainly in the nucleus, although it is also present in the other cell compartments (mitochondria, endoplasmic reticulum). The S1P pool synthesized by this isoform is demonstrated to exert an anti-proliferative and pro-apoptotic effect $[22,29]$. S1P synthesized by Sphk2 enhances histone H3 acetylation and is involved in regulation of genes encoding the cyclin-dependent kinase inhibitor p21 and c-fos [19]. The latest data reported by Takasugi et al. [52] indicated that the S1P pool synthesized by Sphk2 regulates $\beta$-amyloid $(A \beta)$ precursor protein (APP) cleaving enzyme 1 (BACE1) activity and the $A \beta$ level. Sphk 1 resides predominantly in the cytosol and is translocated to the plasma membrane followed by ERK1/2-mediated phosphorylation [39,45,47]. Sphk1 is well known to synthesize the S1P pool, which exerts pro-survival effects within the cells. Sphk1 can be stimulated in response to neuronal growth factor and cytokines $[13,32,46,58]$. The S1P pool synthesized by Sphk1 can promote cell survival, proliferation and migration, and can also regulate differentiation, neurogenesis, angiogenesis, carcinogenesis and inflammation [16,33,50]. The level of intracellular S1P is regulated not only by Sphks but also by enzymes involved in its degradation, that means by S1P lyase (SPL) and by specific S1P phosphatase (SPP1) and also by less-specific SPP2 and other phosphatases (Fig. 1) [36,37]. S1P formed at the plasma membrane can be easily exported from the cell and can act in an autocrine or paracrine fashion through five specific $G$ protein-coupled receptors (S1P1-S1P5), located in sphingolipid microdomains of cell membranes [49]. It is known that sphingolipids play a very important role in Alzheimer's disease (AD). However, there are only a few data about the involvement of sphingolipid metabolism in the pathogenesis/pathomechanism of Parkinson's disease (PD). Brugg et al. [28] reported that dopaminergic neurons in PD undergo apoptosis through a ceramide-dependent mechanism [5]. Recent observations indicated that heterozygous mutations in glucocerebrosidase (GBA), which catalyses the breakdown of glucosylceramide to ceramide and glucose, predispose to PD [28]. A recent study by Abbott et al. [1] showed an altered level of ceramide and ceramide synthase- 1 gene expression in PD anterior cingulate cortex, containing Lewy body pathology. The main component of a Lewy body is $\alpha$-synuclein (ASN), a small presynaptic protein that easily changes conformation under different types of stress $[54,56]$. Overexpression of ASN or its mutation plays a crucial role in PD pathogenesis/pathomechanism $[40,56]$. The ASN mutation is responsible for the familiar form of PD. ASN can be secreted from the cells and can act not only intra- but also extracellularly and can transmit protein pathology from cell to cell [56]. ASN is most toxic in the form of oligomers $[20,56]$. It was observed that ASN binds with high affinity to glycolipoprotein microdomains termed lipid rafts, which are enriched in sphingolipids [15]. The relationship between sphingolipids and ASN in neurodegeneration remains poorly understood. A study by Gómez-Santos et al. (2002) showed that MPP+ increases ASN expression in SH-SY5Y

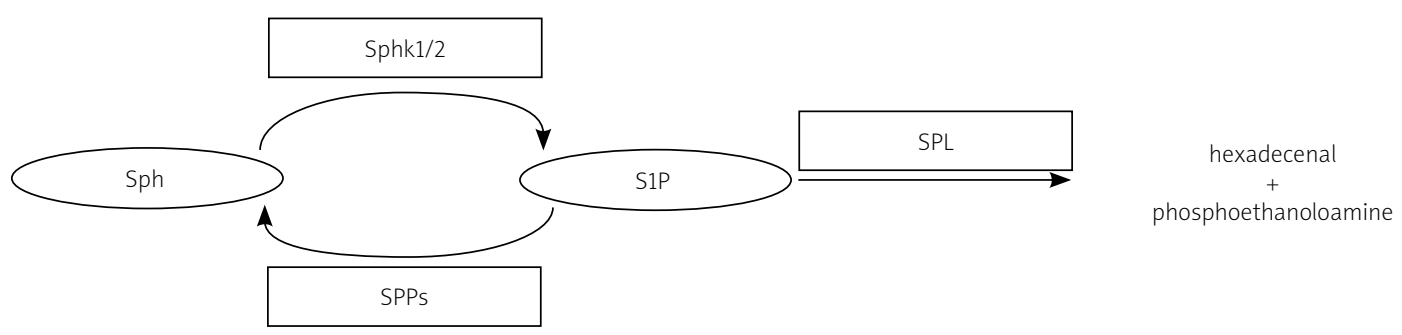

Sph - sphingosine, Sphk1/2 - sphingosine kinases 1/2, SPL - S1P lyase, SPPS - S1P phosphatases, S1P-sphingosine 1-phosphate

Fig. 1. Schematic representation of sphingosine-1-phosphate metabolic pathway. 
cells and suggested that ASN could play an important role in this cellular model of PD [18]. Our latest data demonstrated that MPP+ and Sphks inhibition enhanced the free radical level and down-regulated Sphk1 expression and activity in the SH-SY5Y. Moreover, we observed that S1P protected against MPP+ evoked oxidative stress and alteration of gene expression for Sphk1 and for pro-apoptotic proteins (Bax, Hrk/DP5). S1P significantly enhanced cell viability mainly by activation of S1P1 receptor mediated signalling [41]. In our previous and in this study we used human dopaminergic SH-SY5Y cells, because they express tyrosine hydroxylase $(\mathrm{HT})$, dopamine $\beta$-hydroxylase ( $\mathrm{DBH})$ [38] and the dopamine transporter (DAT) $[24,51,59]$ and have been widely used to gain a better understanding of the molecular processes and pathomechanism of PD. In the present study we investigated gene expression for Sphk1/2 and for enzymes involved in S1P degradation (SPL and SPP). Moreover, we analyzed the role of Sphks activity inhibition in ASN secretion and in the molecular mechanism of neuronal cell death in oxidative stress induced by MPP+.

\section{Material and methods}

\section{Cell culture}

The studies were carried out using the human neuroblastoma cell line SH-SY5Y, control (non-transfected) and transfected with the human gene for alpha-synuclein (ASN), SH-SY5Y-T, or with an empty vector, SH-SY5Y-V (a kind gift from Prof. Nakamura, Kobe University Graduate School of Medicine, Japan; control SH-SY5Y cells were a kind gift from Prof. Anne Eckert, Neurobiology Laboratory for Brain Aging and Mental Health, Psychiatric University Clinics, University of Basel). The cells were cultured in MEM/F-12 Ham Nutrient Mixtures (1:1) supplemented with $15 \%$ heat-inactivated fetal bovine serum (FBS), $1 \%$ penicillin/streptomycin and $2 \mathrm{mM}$ glutamine. The cells were maintained at $37^{\circ} \mathrm{C}$ in a humidified incubator containing $5 \% \mathrm{CO}_{2}$. For the experiments, SH-SY5Y control cells were sub-cultured into collagen-coated $100 \mathrm{~mm}^{2}$ dishes. Prior to treatment, the medium was changed to low-serum medium (2\% FBS). SH-SY5Y cells transfected with the gene for ASN and with the empty vector were sub-cultured into 6-well clusters at $4 \times 10^{4}$ cells/well and differentiated with $10 \mu \mathrm{M}$ all-trans-retinoic acid (ATRA) for
5 days. Prior to treatment, the medium was changed to a serum-free medium with $10 \mu \mathrm{M}$ ATRA.

\section{Cell treatment protocols}

SH-SY5Y control cells (non-transfected) were treated with $3 \mathrm{mM} \mathrm{MPP}+$ (Sigma-Aldrich), with the Sphk1 inhibitor (SKI II $5 \mu \mathrm{M}$, Sigma-Aldrich) or with staurosporine (100 nM, Sigma-Aldrich) for 3-24 h. In some experiments the cells were pre-incubated with $1 \mu$ M S1P (Enzo Life Sciences) or with the caspase inhibitor (Z-VAD-FMK $20 \mu \mathrm{M}$, R\&D Systems) added to the culture medium 1-2 h before MPP+, SKI II treatment or staurosporine treatment. SH-SY5Y-T or SH-SY5Y-V were treated with $1 \mathrm{mM} \mathrm{MPP+}$ or with $1 \mu \mathrm{M}$ SKI II for $24 \mathrm{~h}$.

\section{Assay of alpha-synuclein precipitation and immunochemical detection}

The extracellular medium from SH-SY5Y treated cells and transfected with the ASN gene or with the empty vector was collected and rapidly frozen in liquid nitrogen for $0.5 \mathrm{~h}$. After thawing at $95^{\circ} \mathrm{C}, 50 \mu \mathrm{g}$ of BSA as a carrier protein was added. Protein precipitation was carried out by the addition of $100 \%$ TCA and incubating for $0.5 \mathrm{~h}$ at room temperature (RT). This mixture was then centrifuged at $13000 \times \mathrm{g}$ for $4 \mathrm{~min}$. Then the pellet was washed twice with $1.5 \mathrm{ml}$ and 0.2 $\mathrm{ml}$ of cold acetone and centrifuged at $13000 \times \mathrm{g}$ for 4 min. The pellet was dried at $95^{\circ} \mathrm{C}$ for $10 \mathrm{~min}$ to remove acetone, then resuspended in $25 \mu$ of PBS and incubated at RT for $1 \mathrm{~h}$. The pellet was denatured with $0.55 \mathrm{M}$ Tris-based sample buffer $(\mathrm{pH}=6.8)$ for $10 \mathrm{~min}$. $40 \mu \mathrm{g}$ of proteins were loaded into $15 \%$ polyacrylamide denaturing gels and subjected to electrophoresis (applied constant voltage, $100 \mathrm{~V}$ ). After protein separation, each gel was placed on a nitrocellulose membrane (Amersham Biosciences) in a transfer buffer and the proteins were transferred to the membrane by applying $50 \mathrm{~V}$ for $2 \mathrm{~h}$. After the transfer was completed the ASN level was detected by immunochemical reaction (Western blot) analysis. In order to block non-specific binding, the membrane was incubated at RT for $1 \mathrm{~h}$ in 5\% dried skimmed milk and 0.3\% Tween 20 in phosphate-buffered saline (PBS), pH 7.4. Incubation with primary antibody (anti- $\alpha$ synuclein $1: 1000$ dilution, Sigma-Aldrich) in PBS with $0.1 \%$ Tween 20 and $1 \%$ bovine serum albumin (BSA) was performed overnight at $4^{\circ} \mathrm{C}$. Then the blots were washed three times for $15 \mathrm{~min}$ at RT in PBS with 0.1\% Tween 20. 
The membranes were then incubated with horseradish peroxidase (HRP)-conjugated anti-rabbit IgG secondary antibody diluted $1: 800$ (Sigma-Aldrich) at RT for $1 \mathrm{~h}$. Then the blots were washed as described above and bound antibodies were visualised by enhanced chemiluminescence (Thermo Scientific). Incubation with the anti- $\beta$-actin antibody additionally confirmed equal protein loading.

\section{Cell viability analysis}

Mitochondrial function and cellular viability were evaluated by using 2-(4,5-dimethylthiazol-2-yl)-2,5diphenyltetrazolium bromide (MTT). After $24 \mathrm{~h}$ incubation with appropriate compounds, MTT $(2.5 \mathrm{mg} / \mathrm{ml})$ was added to all of the wells. The cells were incubated at $37^{\circ} \mathrm{C}$ for $2 \mathrm{~h}$. Then the cells were lysed in DMSO and spectrophotometric measurement at $595 \mathrm{~nm}$ was performed.

\section{Preparation of the subcellular fraction}

Preparation of the subcellular fraction was performed as described previously by Cieślik et al. (2013) [8]. Cells were washed and scraped into ice-cold PBS and were pelleted at $1000 \mathrm{rpm}$ for $3 \mathrm{~min}$ at $4^{\circ} \mathrm{C}$. The pellet was resuspended in hypotonic buffer (10 mM Tris, pH 7.4, 1 mM EDTA, 1 mM EGTA, 1 mM DTT, $1.5 \mathrm{mM} \mathrm{MgCl}_{2}, 10 \mathrm{mM} \mathrm{KCl}$ and protease inhibitor cocktail). The homogenate was prepared using a 26-gauge needle (10 passes). Then it was pelleted at $500 \mathrm{~g}$ for $10 \mathrm{~min}$ at $4^{\circ} \mathrm{C}$. The pellet (P1, the crude nuclear fraction) was resuspended in $25 \mathrm{mM}$ Tris, $\mathrm{pH} 7.4$ with protease inhibitors and was used for Western blot analysis. The supernatant (S1) was centrifuged at $15000 \mathrm{~g}$ for $15 \mathrm{~min}$ at $4^{\circ} \mathrm{C}$ to obtain a cytosolic (S2) and crude mitochondrial fraction (P2).

\section{Measurement of Sphk1 and Sphk2 activity}

Sphk activity assay was performed according to a previous report [52]. The pellet, P1 (the crude nuclear fraction), or supernatant, S1 (cytosolic together with the crude mitochondrial fraction), was resuspended in lysis buffer and used for enzymatic reaction. A total of $100 \mu \mathrm{g}$ of protein of $\mathrm{P} 1, \mathrm{~S} 1$ and NBD-Sphingosine (10 $\mu \mathrm{M}$; Avanti Polar Lipids) was mixed in the reaction buffer (50 mM HEPES, $\mathrm{pH} 7.4$, $15 \mathrm{mM} \mathrm{MgCl}_{2}, 0.5 \mathrm{mM} \mathrm{KCl}, 10 \%$ glycerol, and $2 \mathrm{mM}$ ATP) and incubated in a final volume of $100 \mu \mathrm{l}$ for $30 \mathrm{~min}$ at $30^{\circ} \mathrm{C}$. The reactions were stopped by the addition of an equal amount of $1 \mathrm{M}$ potassium phosphate, $\mathrm{pH} 8.5$, followed by the addition of $500 \mu \mathrm{l}$ of chloroform/methanol $(2: 1)$, and then centrifuged at $15000 \mathrm{rpm}$ for $1 \mathrm{~min}$. The reactant NBD-S1P (but not the substrate NBD-Sphingosine) was collected into the alkaline aqueous phase. After the aqueous phase was combined with an equal amount of dimethylformamide, the fluorescence value was measured ( $\lambda$ ex $=485 \mathrm{~nm}, \lambda \mathrm{em}=538 \mathrm{~nm}$ )

\section{Determination of PARP-1 and cytochrome c protein level}

After protein measurement according to Lowry, the homogenate of SH-SY5Y cells and the mitochondrial fraction were mixed with $5 \times$ Laemmli sample buffer and denatured for $5 \mathrm{~min}$ at $95^{\circ} \mathrm{C}$. A total of $40 \mu \mathrm{g}$ of protein was loaded per lane on $10 \%$ acrylamide gels and examined by SDS-PAGE. The proteins were transferred onto PVDF membranes at $100 \mathrm{~V}$. The membranes were incubated in $5 \%$ dry milk in TBS with Tween 20 (TBS-T) for $1 \mathrm{~h}$ and exposed overnight to specific antibodies: anti-cytochrome $c$ (1 : 750, from Santa Cruz Biotechnology), anti-Actin (1 : 4000, from MP Biomedicals), anti-PARP-1 (1: 500, from Sigma-Aldrich), anti-phospho-Akt (Ser473) and anti-Akt ( 1 : 750, Cell Signaling). After treatment for $1 \mathrm{~h}$ with horseradish-peroxidase-coupled secondary antibodies (anti-rabbit from Amersham Biosciences or anti-mouse from GE Healthcare), the protein bands were detected by ECL reagent (Thermo Scientific). Then the membranes were treated with stripping buffer (50 mM glycine, $\mathrm{pH} 2.5,1 \%$ SDS) for further blots.

\section{Analysis of the mRNA level using real-time PCR}

RNA was isolated using a TRI reagent from Sigma-Aldrich. The isolated RNA was dissolved in RNasefree water (Ambion). The amount and purity of the RNA were determined using spectrophotometric measurement at 260 and $280 \mathrm{~nm}$. The OD260/OD280 ratio of the RNA samples ranged from 1.8 to 2.0. Isolated RNA ( $5 \mu \mathrm{g})$ was treated with DNase and then used in RT-PCR. Reverse transcription was performed by using a High Capacity cDNA Reverse Transcription Kit according to the manufacturer's protocol (Applied Biosystems). Quantitative PCR was performed by using pre-developed TaqMan Gene Expression Assays (Applied Biosystems): actb Hs99999903_m1, 


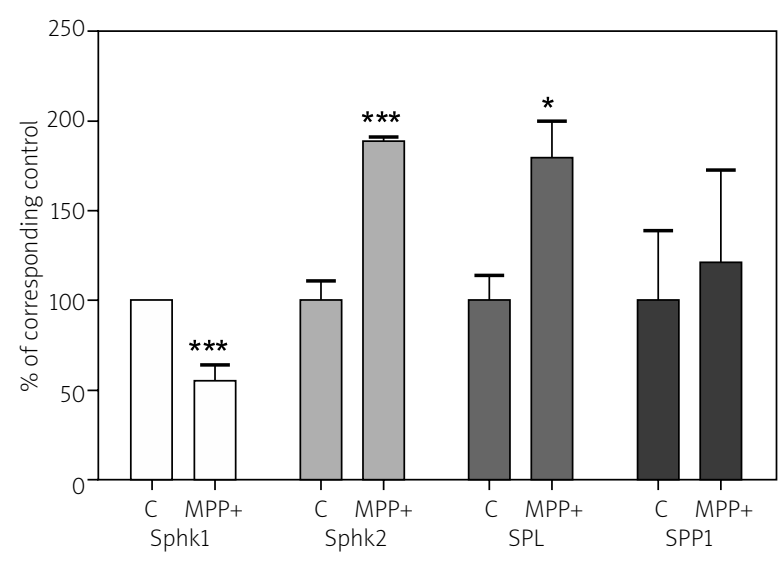

Fig. 2. Sphk1/2, SPL and SPP1 gene expression in MPP+-treated SH-SY5Y cells. SH-SY5Y cells were treated with MPP+ $(3 \mathrm{mM})$ for $12 \mathrm{~h}$. The mRNA level for Sphk1/2, SPL and SPP1 was normalized against $\beta$-actin (Actb). The relative level of mRNA was calculated by the $\Delta \Delta$ Ct method. Data represent the mean value \pm S.E.M from three independent experiments with three replications. Student's $t$-test was used. ${ }^{*} p<0.05,{ }^{* * *} p<0.001$ - vs. control (non-treated) SH-SY5Y cells

A

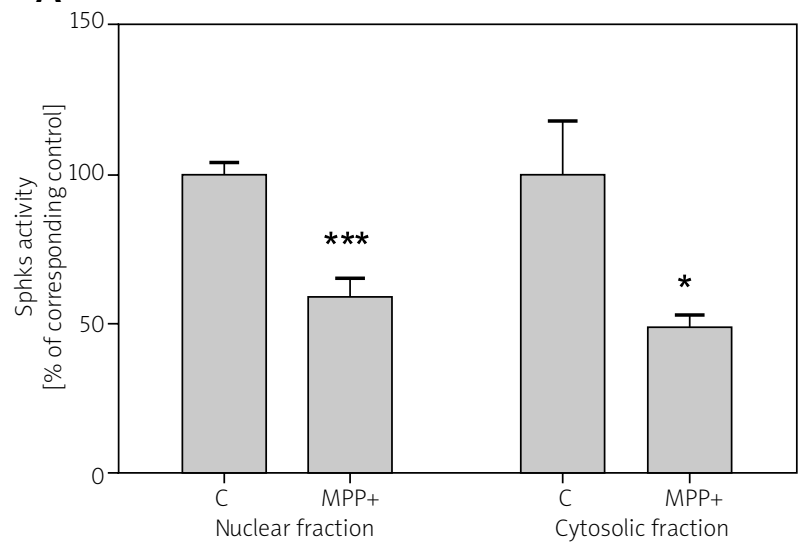

bax Hs00180269_m1, hrk Hs02621354_s1, sphk1 Hs01116530_g1, sphk2 Hs01016543_g1, sgpl1 Hs00187407_m1, sgpp1 Hs00229266_m1 on an ABI PRISM 7500 apparatus according to the manufacturer's instructions. Actb was selected and used in all of the studies as a reference gene. The level of mRNA was calculated by the $\Delta \Delta \mathrm{Ct}$ method.

\section{Statistical analysis}

The results were expressed as mean values \pm S.E.M. Differences between means were analysed using Student's t-test or one-way ANOVA followed by the Newman-Keuls post hoc test. Values of $p<0.05$ were considered statistically significant.

\section{Results}

Human dopaminergic cells (SH-SY5Y) were exposed to $3 \mathrm{mM} \mathrm{MPP}+$ for $24 \mathrm{~h}$. Significant changes in the gene expression level for enzymes involved in the synthesis and degradation of S1P in MPP+-treated SH-SY5Y cells took place. It was observed that MPP+ reduced gene expression for Sphk1 and up-regulated Sphk2. These changes were accompanied by signif-



Fig. 3. Sphk1/2 activity in MPP+-treated SH-SY5Y cells and the role of Sphks inhibition and MPP+ in ASN release from the SH-SY5Y-T cells. A) SH-SY5Y cells were treated with MPP+ (3 mM) for $24 \mathrm{~h}$. Sphks activity was measured in the cytosolic and crude nuclear fraction. Data represent the mean value \pm S.E.M from three independent experiments with two replications. Student's $t$-test was used; ${ }^{\star} p<0.05,{ }^{* * *} p<0.001-$ vs. control (non-treated) SH-SY5Y cells. B) SH-SY5Y-T cells were treated with MPP+ (1 mM) and SKI II (1 $\mu M$ ) for 24 h. Control represents non-treated SH-SY5Y-T cells. The immunochemical level of ASN in the extracellular buffer was detected. Data represent the mean value \pm S.E.M from three independent experiments. Student's $t$-test was used. ${ }^{*} p<0.05,{ }^{* *} p<0.01-$ vs. control (non-treated) SH-SY5Y-T cells. 
A

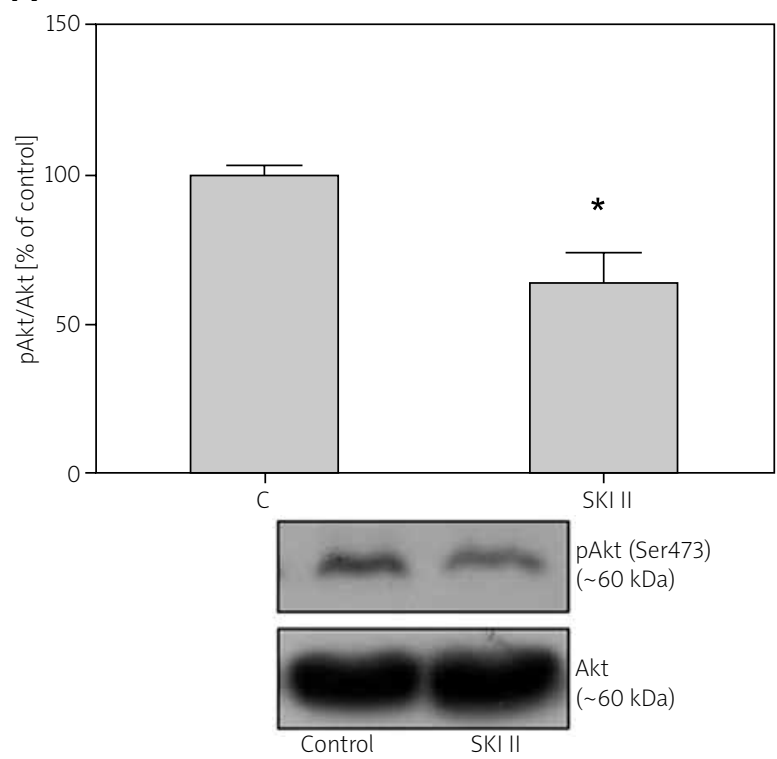

C

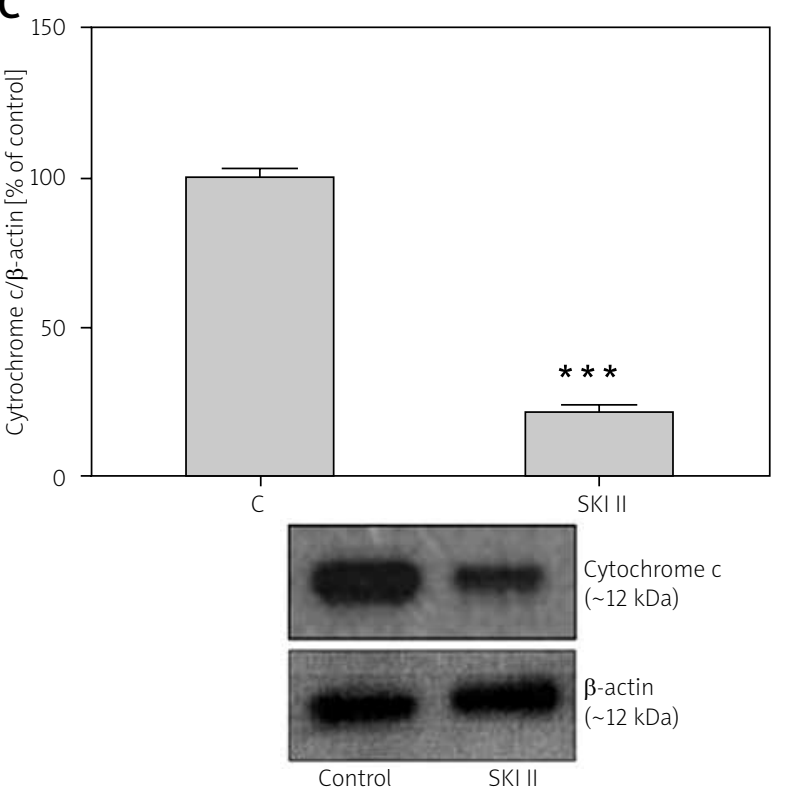

B

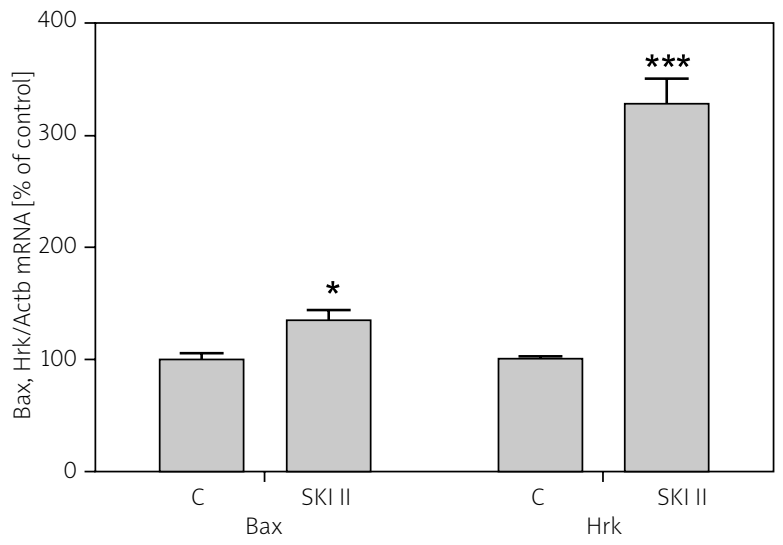

D

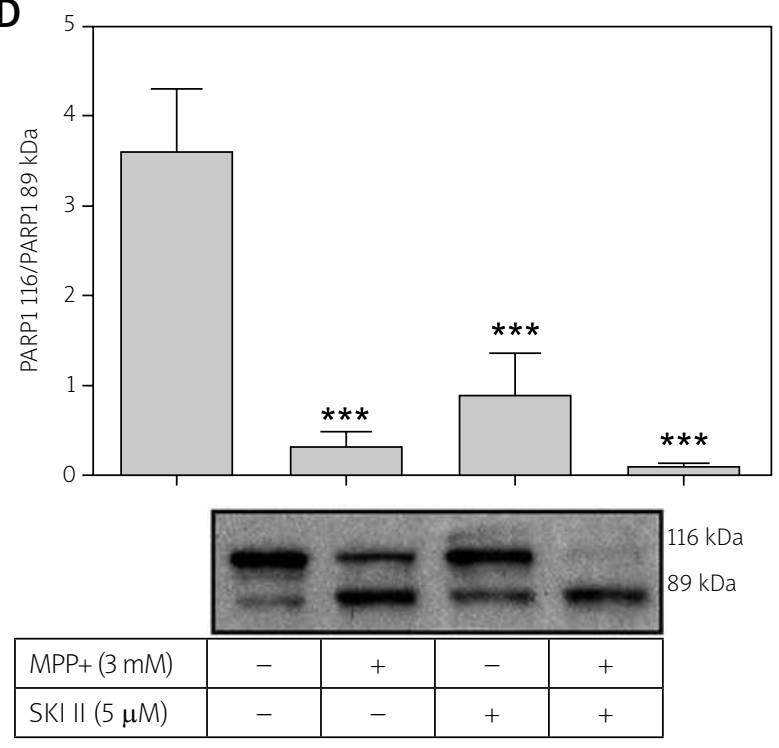

Fig. 4. Effect of Sphks inhibition (using SKI II) on Akt phosphorylation, Bax and Hrk gene expression, level of cytochrome $\mathrm{c}$ in the mitochondrial fraction and PARP1 degradation. A) SH-SY5Y cells were treated with SKI II $(5 \mu \mathrm{M})$ for $24 \mathrm{~h}$. Immunochemical detection of pAkt(Ser473)/Akt in cell homogenate was measured. Data represent the mean value \pm S.E.M from four independent experiments. Student's $t$-test was used. ${ }^{*} p<0.05$ - vs. control (non-treated) SH-SY5Y cells. B) The mRNA level for Bax and Hrk was normalized against $\beta$-actin (Actb). The relative level of mRNA was calculated by the $\Delta \Delta \mathrm{Ct}$ method. Data represent the mean value \pm S.E.M from three independent experiments with three replications. Student's $t$-test was used. ${ }^{*} p<0.05,{ }^{* \star *} p<0.001-$ vs. control (non-treated) SH-SY5Y cells. C) Immunochemical detection of cytochrome $c / \beta$-actin in the mitochondrial fraction was measured. Data represent the mean value \pm S.E.M from four independent experiments. Student's $t$-test was used. ${ }^{* *} p<0.001-v s$. control (non-treated) SH-SY5Y cells. D) SH-SY5Y cells were treated with $3 \mathrm{mM} \mathrm{MPP+,} 5 \mu \mathrm{M}$ SKI II and with both compounds together for $24 \mathrm{~h}$. The immunochemical detection of PARP1 $116 \mathrm{kDa} / \mathrm{PARP} 189 \mathrm{kDa}$ in cell homogenate was measured. Data represent the mean value \pm S.E.M from four independent experiments. One-way ANOVA followed by the Newman-Keuls post-hoc test was used. ${ }^{* \star *} p<0.001-v$ s. control (non-treated) SH-SY5Y cells. 


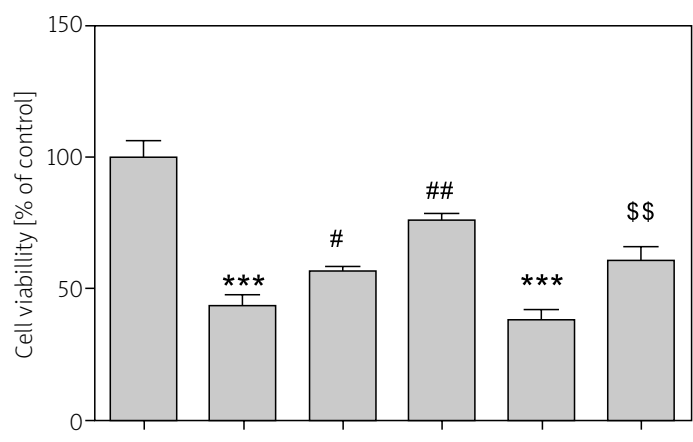

\begin{tabular}{|l|c|c|c|c|c|c|}
\hline $\mathrm{MPP}+3 \mathrm{mM}$ & - & + & + & + & - & - \\
\hline $\begin{array}{l}\text { Z-VAD-FMK } \\
20 \mu \mathrm{M}\end{array}$ & - & - & + & - & - & + \\
\hline $\mathrm{S} 1 \mathrm{P} 1 \mu \mathrm{M}$ & - & - & - & + & - & - \\
\hline $\begin{array}{l}\text { Staurospo- } \\
\text { rine 100 nM }\end{array}$ & - & - & - & - & + & + \\
\hline
\end{tabular}

Fig. 5. Effect of caspase inhibitor and S1P on MPP+-treated SH-SY5Y cell viability. SH-SY5Y cells were treated with caspase inhibitor $(20 \mu \mathrm{M}$ Z-VAD-FMK) for $2 \mathrm{~h}$ or with $1 \mu \mathrm{M} \mathrm{S1P}$ for $1 \mathrm{~h}$ and then exposed to $3 \mathrm{mM} \mathrm{MPP+}$ or $100 \mathrm{nM}$ staurosporine for $24 \mathrm{~h}$. Cell viability was determined using MTT assay. Data represent the mean value \pm S.E.M from four independent experiments with 4-6 replications. One-way ANOVA followed by the Newman-Keuls post-hoc test was used. ${ }^{* * *} p<0.001$ vs. control (non-treated) SH-SY5Y cells; ${ }^{*} p<0.05$, ${ }^{\#} p<0.01$ vs. MPP+-treated cells; ${ }^{\$ \$}<0.01-$ vs. staurosporine-treated cells.

icant enhancement of mRNA for SPL, but there was no alteration of S1P phosphatase (SPP1) gene expression (Fig. 2). In these stress conditions, Sphk1 activity in the cytosolic fraction and Sphk2 in the nuclear fraction were measured. Spectrofluorometric analysis indicated that the activity of both enzymes was reduced in MPP+-treated cells (Fig. 3A). Subsequently, we examined the effect of Sphks inhibitor (SKI II $1 \mu \mathrm{M})$ and MPP+ (1 mM) (at a concentration that did not change cell viability) on ASN secretion from ASN-transfected cells (SH-SY5Y-T and SH-SY5Y-V). Our data indicated that these compounds significantly enhanced ASN release into the extracellular space (Fig. 3B). Then the role of Sphks inhibition in other molecular events involved in neuronal death, evoked by MPP+, was analyzed. Here we found that the Sphks inhibitor ( $5 \mu \mathrm{M}$ SKI II) caused significant suppression of $\mathrm{PI} 3 \mathrm{~K} / \mathrm{Akt}$ phosphorylation/activity
(Fig. 4A) and an increase in gene expression for the pro-apoptotic Bcl-2 proteins Bax and Hrk (Fig. 4B). Moreover, Sphks inhibition by $5 \mu$ M SKI II significantly reduced the level of cytochrome $c$ in the mitochondrial fraction from the SH-SY5Y cells (Fig. 4C). It was also demonstrated that Sphks inhibition led to degradation of nuclear enzyme poly(ADP-ribose) polymerase PARP1, the preferential substrate for caspase 3 (Fig. 4D). A similar effect of PARP1 degradation was evoked by MPP+. Inhibitor of caspases (20 $\mu \mathrm{M}$ Z-VAD-FMK) enhanced cell viability in MPP+ evoked oxidative stress. However, $1 \mu \mathrm{M}$ S1P exerts a more efficient neuroprotective effect (Fig. 5).

\section{Discussion}

In this study we analysed the role of Sphks inhibition on ASN secretion and in the molecular mechanism of dopaminergic neuronal death in oxidative stress evoked by MPP+. We found altered gene expression and activity of both Sphk1 and Sphk2. The activity of both kinases was significantly decreased in MPP+-evoked stress. We demonstrated that Sphks inhibition evoked death signalling by stimulation of ASN secretion and several molecular events, including inhibition of PI3K/Akt, activation of pro-apoptotic protein expression, release of cytochrome $\mathrm{c}$ from the mitochondria and caspase-dependent apoptosis. PI3K/Akt participates in Bax phosphorylation and in stabilization of Bad/14-3-3 complexes $[12,42,48]$. These events protect against translocation of the pro-apoptotic proteins from the cytosol to the mitochondria and reduce cell death. Several studies have found that S1P, synthesized by Sphk1, is responsible for promoting pro-survival processes through PI3K/Akt $[27,31,35]$. Here we demonstrated that inhibition of Sphks/S1P formation by SKI II reduced PI3K/Akt phosphorylation on Serine 473 and reduced its activity. Subsequently, these events may reduce BAD phosphorylation. In our experiments we observed lower BAD phosphorylation, but the results were statistically insignificant (data not shown). In this study we found that inhibition of Sphks induced significant up-regulation of Bax and Hrk. Both of these pro-apoptotic proteins are engaged in alteration of mitochondrial membrane potential/permeability and cytochrome c release. Lower content of cytochrome $c$ in mitochondria was observed in our study. It was previously demonstrated that S1P regulates cell survival/death through Bcl-2 proteins $[3,4,9,26,43]$. Exogenous S1P $(1 \mu \mathrm{M})$ 
enhanced the expression of anti-apoptotic $\mathrm{Bcl}-2$ protein and cell survival in oxidative stress evoked by ceramide [11]. Recently, we demonstrated that S1P $(1 \mu M)$ reduced the Bax and Hrk mRNA level in MPP+-treated SH-SY5Y cells [41]. In this study we observed that S1P $(1 \mu M)$ exerted a more efficient neuroprotective effect than the caspase inhibitor. There are no data showing Sphk1/S1P alteration in the PD human brain, as opposed to several post-mortem studies on AD brains demonstrating disturbances in sphingolipid metabolism, including changes in the expression of Sphk1/2, SPL and SPP $[6,21,23]$. It was shown that Sphk1 and Sphk2 activity declined concomitantly with progression of $A D$ pathology in the hippocampus and in temporal grey matter. Subsequently, the S1P/sphingosine ratio decreased in parallel with an increase in neuropathological changes as described in Braak stages in AD [10]. Recent data demonstrated ceramide and lipid rafts alterations in PD $[7,14,15]$. It was found that reduced glucocerebrosidase and, in consequence, accumulation of glucosylceramide are associated with an increased ASN level in sporadic PD [34]. The data of Martinez et al. [30], Czubowicz and Strosznajder [11] demonstrated that ceramide dose-dependently reduced the viability of primary dopaminergic neurons and neuroblastoma cells respectively. Moreover, the data of Martinez et al. [30] showed that the inhibitors of sphingomyelinases protected dopaminergic neurons against ceramide formation, endoplasmic stress, caspase 3 activation and decrease in Akt phosphorylation. Our data suggest that inhibition of Sphks could be responsible for the transient enhancement of sphingosine and for the accumulation of ceramide. The latest study by Murphy et al. [34] indicated a significant relationship between lipids and ASN in PD. Our results demonstrated that inhibition of Sphks leads to ASN secretion from dopaminergic neuronal cells. Sphks inhibition and S1P have no effect on ASN gene expression and protein level (data not shown). It was found that MPP+ also evoked ASN release. A previous study suggested that ASN might be a key player in oxidative stress and in MPP+-induced mitochondrial dysfunction of SH-SY5Y cells [57]. Oxidative/nitrosative stress, evoked by different experimental conditions, leads to ASN release from the brain synaptosomal fraction [2]. It seems that in our experimental conditions, the enhanced free radical level and oxidative stress could also be involved in
ASN release. Extracellular ASN may be responsible for propagation of pathology from cell to cell. ASN oligomerisation causes oxidative stress and leads to mitochondrial failure and cell death. A rapidly growing amount of evidence indicates that extracellular ASN in oligomeric form contributes to PD pathology $[25,56]$. In summary, our data indicate that Sphk1 inhibition plays an important role in ASN release and in caspase-dependent apoptotic dopaminergic neuronal death in the experimental PD model.

\section{Acknowledgement}

Supported by NCN Grant 5870/B/PO1/2011/40.

\section{Disclosure}

Authors report no conflict of interest.

\section{References}

1. Abbott SK, Li H, Muñoz SS, Knoch B, Batterham M, Murphy KE, Halliday GM, Garner B. Altered ceramide acyl chain length and ceramide synthase gene expression in Parkinson's disease. Mov Disord 2014; 29: 518-526.

2. Adamczyk A, Kacprzak M, Kazmierczak A. Alpha-synuclein decreases arachidonic acid incorporation into rat striatal synaptoneurosomes. Folia Neuropathol 2007; 45: 230-235.

3. Bektas M, Jolly PS, Müller C, Eberle J, Spiegel S, Geilen CC. Sphingosine kinase activity counteracts ceramide-mediated cell death in human melanoma cells: role of Bcl-2 expression. Oncogene 2005; 24: 178-187.

4. Betito S, Cuvillier O. Regulation by sphingosine 1-phosphate of Bax and Bad activities during apoptosis in a MEK-dependent manner. Biochem Biophys Res Commun 2006; 340: 1273-1277.

5. Brugg B, Michel PP, Agid Y, Ruberg M. Ceramide induces apoptosis in cultured mesencephalic neurons. Neurochem J 1996; 66: 733-739.

6. Ceccom J, Loukh N, Lauwers-Cances V, Touriol C, Nicaise Y, Gentil C, Uro-Coste E, Pitson S, Maurage CA, Duyckaerts C, Cuvillier O, Delisle MB. Reduced sphingosine kinase-1 and enhanced sphingosine 1-phosphate lyase expression demonstrate deregulated sphingosine 1-phosphate signaling in Alzheimer's disease. Acta Neuropathol Commun 2014; 2: 12.

7. Cheng D, Jenner AM, Shui G, Cheong WF, Mitchell TW, NeaIon JR, Kim WS, McCann H, Wenk MR, Halliday GM, Garner B. Lipid pathway alterations in Parkinson's disease primary visual cortex. PLoS One 2011; 6: e17299.

8. Cieslik M, Pyszko J, Strosznajder JB. Docosahexaenoic acid and tetracyclines as promising neuroprotective compounds with poly(ADP-ribose) polymerase inhibitory activities for oxidative/ genotoxic stress treatment. Neurochem Int 2013; 62: 626-636.

9. Colié S, Van Veldhoven PP, Kedjouar B, Bedia C, Albinet V, Sorli SC, Garcia V, Djavaheri-Mergny M, Bauvy C, Codogno P, Levade T, Andrieu-Abadie N. Disruption of sphingosine 1-phosphate lyase confers resistance to chemotherapy and promotes 
oncogenesis through $\mathrm{Bcl}-2 / \mathrm{Bcl}-\mathrm{xL}$ up-regulation. Cancer Res 2009; 69: 9346-9353.

10. Couttas TA, Kain N, Daniels B, Lim XY, Shepherd C, Kril J, Pickford R, Li H, Garner B, Don AS. Loss of the neuroprotective factor Sphingosine 1-phosphate early in Alzheimer's disease pathogenesis. Acta Neuropathol Commun 2014; 2: 9.

11. Czubowicz K, Strosznajder R. Ceramide in the Molecular Mechanisms of Neuronal Cell Death. The Role of Sphingosine-1-Phosphate. Mol Neurobiol 2014; doi: 10.1007/s12035-013-8606-4.

12. Datta SR, Dudek H, Tao X, Masters S, Fu H, Gotoh Y, Greenberg ME. Akt phosphorylation of BAD couples survival signals to the cell-intrinsic death machinery. Cell 1997; 91: 231-241.

13. Edsall LC, Pirianov GG, Spiegel S. Involvement of sphingosine 1-phosphate in nerve growth factor-mediated neuronal survival and differentiation. J Neurosci 1997; 17: 6952-6960.

14. Fabelo N, Martín V, Santpere G, Marín R, Torrent L, Ferrer I, Díaz M. Severe alterations in lipid composition of frontal cortex lipid rafts from Parkinson's disease and incidental Parkinson's disease. Mol Med 2011; 17: 1107-1118.

15. Fortin DL, Troyer MD, Nakamura K, Kubo S, Anthony MD, Edwards RH. Lipid rafts mediate the synaptic localization of alpha-synuclein. J Neurosci 2004; 24: 6715-6723.

16. Fyrst H, Saba JD. An update on sphingosine-1-phosphate and other sphingolipid mediators. Nat Chem Biol 2010; 6: 489-497.

17. Giasson B, Duda JE, Murray IV, Chen Q, Souza JM, Hurtig HI, Ischiropoulos H, Trojanowski JQ, Lee VM. Oxidative damage linked to neurodegeneration by selective alpha-synuclein nitration in synucleinopathy lesions. Science 2000; 290: 985-989.

18. Gómez-Santos C, Ferrer I, Reiriz J, Viñals F, Barrachina M, Ambrosio S. MPP+ increases alpha-synuclein expression and ERK/MAP-kinase phosphorylation in human neuroblastoma SH-SY5Y cells. Brain Res 2002; 935: 32-39.

19. Hait NC, Allegood J, Maceyka M, Strub GM, Harikumar KB, Singh SK, Luo C, Marmorstein R, Kordula T, Milstien S, Spiegel $\mathrm{S}$. Regulation of histone acetylation in the nucleus by sphingosine-1-phosphate. Science 2009; 325: 1254-1257.

20. Hansen C, Angot E, Bergström AL, Steiner JA, Pieri L, Paul G, Outeiro TF, Melki R, Kallunki P, Fog K, Li JY, Brundin P. $\alpha$-Synuclein propagates from mouse brain to grafted dopaminergic neurons and seeds aggregation in cultured human cells. J Clin Invest 2011; 121: 715-725.

21. He X, Huang Y, Li B, Gong CX, Schuchman EH. Deregulation of sphingolipid metabolism in Alzheimer's disease. Neurobiol Aging 2010; 31: 398-408.

22. Igarashi N, Okada T, Hayashi S, Fujita T, Jahangeer S, Nakamura S. Sphingosine kinase 2 is a nuclear protein and inhibits DNA synthesis. J Biol Chem 2003; 278: 46832-46839.

23. Katsel P, Li C, Haroutunian V. Gene expression alterations in the sphingolipid metabolism pathways during progression of dementia and Alzheimer's disease: a shift toward ceramide accumulation at the earliest recognizable stages of Alzheimer's disease? Neurochem Res 2007; 32: 845-856.

24. Korecka JA, van Kesteren RE, Blaas E, Spitzer SO, Kamstra JH, Smit AB, Swaab DF, Verhaagen J, Bossers K. Phenotypic characterization of retinoic acid differentiated SH-SY5Y cells by transcriptional profiling. PLoS One 2013; 8: e63862.
25. Lee HJ, Bae EJ, Lee SJ. Extracellular $\alpha$-synuclein-a novel and crucial factor in Lewy body diseases. Nat Rev Neurol 2014; 10 : 92-98.

26. Li QF, Wu CT, Guo Q, Wang H, Wang LS. Sphingosine 1-phosphate induces $\mathrm{Mcl}-1$ upregulation and protects multiple myeloma cells against apoptosis. Biochem Biophys Res Commun 2008; 371: 159-162.

27. Limaye V, Li X, Hahn C, Xia P, Berndt MC, Vadas MA, Gamble JR. Sphingosine kinase-1 enhances endothelial cell survival through a PECAM-1-dependent activation of PI-3K/Akt and regulation of Bcl-2 family members. Blood 2005; 105: 3169-3177.

28. Lwin A, Orvisky E, Goker-Alpan O, LaMarca ME, Sidransky E. Glucocerebrosidase mutations in subjects with parkinsonism. Mol Genet Metab 2004; 81: 70-73.

29. Maceyka M, Sankala H, Hait NC, Le Stunff H, Liu H, Toman R, Collier C, Zhang M, Satin LS, Merrill AH Jr, Milstien S, Spiegel S. SphK1 and SphK2, sphingosine kinase isoenzymes with opposing functions in sphingolipid metabolism. J Biol Chem 2005; 280: 37118-37129.

30. Martinez TN, Chen X, Bandyopadhyay S, Merrill AH, Tansey MG. Ceramidesphingolipid signaling mediates Tumor Necrosis Factor (TNF)-dependent toxicity via caspase signaling in dopaminergic neurons. Mol Neurodegener 2012; 7: 45.

31. Means CK, Xiao CY, Li Z, Zhang T, Omens JH, Ishii I, Chun J, Brown JH. Sphingosine 1-phosphate S1P2 and S1P3 receptor-mediated Akt activation protects against in vivo myocardial ischemia-reperfusion injury. Am J Physiol Heart Circ Physiol 2007; 292: H2944-2951.

32. Meyer zu Heringdorf D, Lass H, Kuchar I, Lipinski M, Alemany R, Rumenapp $\mathrm{U}$, Jakobs $\mathrm{KH}$. Stimulation of intracellular sphingosine-1-phosphate production by G-protein-coupled sphingosine1-phosphate receptors. Eur J Pharmacol 2001; 414: 145-154.

33. Mizugishi K, Yamashita T, Olivera A, Miller GF, Spiegel S, Proia RL. Essential role for sphingosine kinases in neural and vascular development. Mol Cell Biol 2005; 25: 11113-11121.

34. Murphy KE, Gysbers AM, Abbott SK, Tayebi N, Kim WS, Sidransky E, Cooper A, Garner B, Halliday GM. Reduced glucocerebrosidase is associated with increased $\alpha$-synuclein in sporadic Parkinson's disease. Brain 2014; 137: 834-848.

35. Nakahara T, Iwase A, Nakamura T, Kondo M, Bayasula, Kobayashi H, Takikawa S, Manabe S, Goto M, Kotani T, Kikkawa F. Sphingosine-1-phosphate inhibits $\mathrm{H} 2 \mathrm{O} 2$-induced granulosa cell apoptosis via the PI3K/Akt signaling pathway. Fertil Steril 2012; 98: 1001-1008.

36. Neubauer HA, Pitson SM. Roles, regulation and inhibitors of sphingosine kinase 2. FEBS I 2013; 280: 5317-5336.

37. Orr Gandy KA, Obeid LM. Targeting the sphingosine kinase/sphingosine 1-phosphate pathway in disease: review of sphingosine kinase inhibitors. Biochim Biophys Acta 2013; 1831: 157-166.

38. Oyarce AM, Fleming PJ. Multiple forms of human dopamine beta-hydroxylase in SH-SY5Y neuroblastoma cells. Arch Biochem Biophys 1991; 290: 503-510.

39. Pitson SM, Moretti PA, Zebol JR, Lynn HE, Xia P, Vadas MA, Wattenberg BW. Activation of sphingosine kinase 1 by ERK1/2-mediated phosphorylation. EMBO I 2003; 22: 5491-5500.

40. Polymeropoulos MH, Lavedan C, Leroy E, Ide SE, Dehejia A, Dutra A, Pike B, Root H, Rubenstein J, Boyer R, Stenroos ES, Chandrasekharappa S, Athanassiadou A, Papapetropoulos T, John- 
son WG, Lazzarini AM, Duvoisin RC, Di lorio G, Golbe LI, Nussbaum RL. Mutation in the alpha-synuclein gene identified in families with Parkinson's disease. Science 1997; 276: $2045-$ 2047.

41. Pyszko J, Strosznajder JB. Sphingosine Kinase 1 and Sphingosine1-Phosphate in Oxidative Stress Evoked by 1-Methyl-4-Phenylpyridinium (MPP+) in Human Dopaminergic Neuronal Cells. Mol Neurobiol 2014; doi: 10.1007/s12035-013-8622-4 [Epub ahead of print].

42. Rosenquist M. 14-3-3 proteins in apoptosis. Braz I Med Biol Res 2003; 36: 403-408.

43. Sauer B, Gonska H, Manggau M, Kim DS, Schraut C, Schäfer-Korting M, Kleuser B. Sphingosine 1-phosphate is involved in cytoprotective actions of calcitriol in human fibroblasts and enhances the intracellular Bcl-2/Bax rheostat. Pharmazie 2005; 60: 298-304.

44. Spiegel S, Milstien S. Sphingosine-1-phosphate: an enigmatic signalling lipid. Nat Rev Mol Cell Biol 2003; 4: 397-407.

45. Stahelin RV, Hwang JH, Kim JH, Park ZY, Johnson KR, Obeid LM, Cho $W$. The mechanism of membrane targeting of human sphingosine kinase 1. J Biol Chem 2005; 280: 43030-43038.

46. Sukocheva OA, Wadham C, Holmes A, Albanese N, Verrier E, Feng F, Bernal A, Derian CK, Ullrich A, Vadas MA, Xia P. Estrogen transactivates EGFR via the sphingosine 1-phosphate receptor Edg-3: the role of sphingosine kinase-1. J Cell Biol 2006; 173: 301-310.

47. Sutherland CM, Moretti PA, Hewitt NM, Bagley CJ, Vadas MA, Pitson SM. The calmodulin binding site of sphingosine kinase and its role in agonist-dependent translocation of sphingosine kinase 1 to the plasma membrane. J Biol Chem 2006; 281: 11693-11701.

48. Szanto A, Bognar Z, Szigeti A, Szabo A, Farkas L, Gallyas F Jr. Critical role of bad phosphorylation by Akt in cytostatic resistance of human bladder cancer cells. Anticancer Res 2009; 29: 159-164.

49. Taha TA, Argraves KM, Obeid LM. Sphingosine-1-phosphate receptors: receptor specificity versus functional redundancy. Biochim Biophys Acta 2004; 1682: 48-55.

50. Takabe K, Paugh SW, Milstien S, Spiegel S. "Inside-out" signaling of sphingosine-1-phosphate: therapeutic targets. Pharmacol Rev 2008; 60: 181-195.

51. Takahashi T, Deng Y, Maruyama W, Dostert P, Kawai M, Naoi M. Uptake of a neurotoxin-candidate, (R)-1,2-dimethyl-6,7-dihydroxy-1,2,3,4-tetrahydroisoquinoline into human dopaminergic neuroblastoma SH-SY5Y cells by dopamine transport system. J Neural Transm Gen Sect 1994; 98: 107-118.

52. Takasugi N, Sasaki T, Suzuki K, Osawa S, Isshiki H, Hori Y, Shimada N, Higo T, Yokoshima S, Fukuyama T, Lee VM, Trojanowski JQ, Tomita T, Iwatsubo T. BACE1 activity is modulated by cell-associated sphingosine-1-phosphate. J Neurosci 2011; 31: 6850-6857.

53. Takuwa Y, Okamoto Y, Yoshioka K, Takuwa N. Sphingosine-1 -phosphate signaling in physiology and diseases. Biofactors 2012; 38: 329-337.

54. Uversky VN, Eliezer D. Biophysics of Parkinson's disease: structure and aggregation of alpha-synuclein. Curr Protein Pept Sci 2009; 10: 483-499.
55. Van Brocklyn JR, Williams JB. The control of the balance between ceramide and sphingosine-1-phosphate by sphingosine kinase: oxidative stress and the seesaw of cell survival and death. Comp Biochem Physiol B Biochem Mol Biol 2012; 163: 26-36.

56. Wilkaniec A, Strosznajder JB, Adamczyk A. Toxicity of extracellular secreted alpha-synuclein: Its role in nitrosative stress and neurodegeneration. Neurochem Int 2013; 62: 776-783.

57. Wu F, Poon WS, Lu G, Wang A, Meng H, Feng L, Li Z, Liu S. Alpha-synuclein knockdown attenuates MPP+ induced mitochondrial dysfunction of SH-SY5Y cells. Brain Res 2009; 1292: 173-179.

58. Xia P, Wang L, Moretti PA, Albanese N, Chai F, Pitson SM, D’Andrea RJ, Gamble JR, Vadas MA. Sphingosine kinase interacts with TRAF2 and dissects tumor necrosis factor-alpha signaling. J Biol Chem 2002; 277: 7996-8003.

59. Xie HR, Hu LS, Li GY. SH-SY5Y human neuroblastoma cell line: in vitro cell model of dopaminergic neurons in Parkinson's disease. Chin Med J (Engl) 2010; 123: 1086-1092. 